\title{
Materials, critical materials and clean-energy technologies
}

\author{
R. $\operatorname{EgGerT}(*)$ \\ Division of Economics and Business, Colorado School of Mines - Golden, 80401 CO, USA
}

Summary. - Modern engineered materials, components and systems depend on raw materials whose properties provide essential functionality to these technologies. Some of these raw materials are subject to supply-chain risks, and such materials are known as critical materials. This paper reviews corporate, national and world perspectives on material criticality. It then narrows its focus to studies that assess "what is critical" to clean-energy technologies. The focus on supply-chain risks is not meant to be alarmist but rather to encourage attention to monitoring these risks and pursuing technological innovation to mitigate the risks.

\section{1. - Introduction}

Modern materials provide essential properties to engineered components and systems - properties such as luminescence, magnetism, thermal conductivity and corrosion resistance. Critical materials provide these and other essential properties and, moreover, are subject to supply-chain risks. Of particular concern in this paper are supply disruptions that might hinder the development and deployment of emerging clean-energy technologies such as electric vehicles, light-emitting-diode (LED) lighting, photovoltaic power systems and wind turbines.

Concern about raw-material availability, or rather limits on availability, is not new. It has been a recurring societal concern. In the middle 1800s, for example, W.S. Jevons

$\left(^{*}\right)$ E-mail: reggert@mines.edu 
explored the exhaustion of coal in Britain [1]. In the late 1800s and early 1900s, dramatic increases in the use of fertilizers in commercial agriculture led to fears about the adequacy of naturally occurring sources of nitrogen, which at the time came from animal dung, urine, and Chilean nitrate deposits $[2,3]$. In the years following World War II, concerns focused on a wide range of mineral raw materials and energy, given the significant use of mineral and energy resources during the war [4]. In the 1970s, attention returned to energy and minerals, in this case concerns about reliability of foreign sources of oil and some nonfuel minerals, as well as long-term adequacy of nonrenewable resources generally and implications for economic growth [5]. In each case, society adjusted to perceived scarcities through one or a combination of three approaches: developing new sources of mineral and energy resources, using resources more efficiently, and developing substitute materials or sources of energy.

The first decade or so of the 21st century witnessed a sustained boom in prices (since reversed) for many energy and mineral commodities, drawing public attention once again to resource availability. Part of this attention has focused on elements that, up until recently, have had limited commercial use. Typically, these elements represent a small part of the mass of an assembly or final product and yet provide essential functionality to the assembly or product - for example, neodymium and dysprosium in permanent magnets, europium and terbium in advanced lighting, indium and tellurium in photovoltaic materials, and lithium in batteries. The attention on these specialty metals led to several efforts to establish a framework for assessing what is "critical".

\section{2. - Methodology}

One of the first to suggest a methodology was a study by a committee of the U.S. National Research Council [6]. It presented a framework for assessing criticality in two dimensions: a) supply risk, or the probability of a supply disruption, and b) the impact of a supply disruption should it occur. Most subsequent studies represent variations on or extensions to this general framework.

The National Research Council (NRC) study notes that the criticality of specific elements changes over time as production technologies evolve and as new materials and products are developed. It also notes that, in the short to medium term, supply disruptions come largely from

- significant and unanticipated increases in demand, especially for elements with small existing markets (for example, rhenium for which annual world demand is on the order of several tens of tonnes),

- concentration of production in a small number of mines, companies, or countries, especially countries with significant political risks (such as cobalt and the geographic concentration of its production in central Africa), and

- production coming predominantly as a by-product (such as indium produced predominantly as a minor by-product of zinc metallurgical operations). 
Over the longer term, mineral availability, or lack of availability, depends importantly on whether investments occur in mineral production and the underlying science and engineering that inform our understanding of mineral occurrence and define processes for efficient mineral exploration, mine development and mining and mineral processing.

The most comprehensive extension to the NRC methodology is Graedel et al. [7]. This paper adds a third dimension to criticality: environmental implications of material production and use. It also articulates important differences in perspective when considering corporations, nations and the world as a whole and defines indicators of criticality for all three dimensions and all three perspectives.

\section{3. - The many faces of criticality}

What is critical depends on the situation, as a number of recent studies illustrate leading to a number of variations on the methodologies described above when assessing material supply chains in specific circumstances.

3`1. Corporate perspectives. - A corporate perspective asks, what materials are essential to a company's financial performance and what supply vulnerabilities put this performance at risk? Corporations are understandably reluctant to reveal their vulnerabilities when it comes to raw-material supply chains. Yet most presumably carry out some type of internal assessment of these vulnerabilities. General Electric (GE) is one of the few to have written publicly about their assessments $[8,9]$, which customize the general framework proposed in the NRC (2008) study discussed earlier. GE evaluated criticality in two dimensions: a) supply and price risk based on historical price volatility, sourcing and geopolitical risk, demand risk, ease or difficulty of substitution, co-production risk, and an element's abundance in the earth's crust; and b) impact on GE of a restriction based on ability to pass-through cost increases to customers, GE's ability to substitute, impacted GE revenue and GE's purchases as a percentage share of world production.

GE's strategy for ensuring raw-material availability consists essentially of the three approaches identified earlier: a) broadening material sources, b) optimizing use of materials through improvements in manufacturing efficiency and recycling and c) redesigning materials and systems, referred to as substitution earlier. Within the last decade, GE used a combination of these approaches to deal with two actual and one anticipated supply disruption. The first actual disruption involved rhenium used in superalloys in various types of turbines. In 2006, rhenium prices increased six-fold. In response, GE developed new relationships with suppliers, improved manufacturing efficiencies, developed new processes to reclaim and re-use rhenium in nickel-based superalloys from end-of-life turbine blades and developed and certified new alloys that contain less or no rhenium. The second actual disruption involved rare earths, which experienced tenfold or greater price increases in 2010-2011. In response, GE is developing recycling technologies, especially for phosphor (lighting) materials, redesigning products to reduce rare-earth content (for example, in fluorescent lights) and developing new systems that use little or no rare earths (for example, LED lights that require fewer rare earths per 
unit of light). The anticipated supply disruption, which was averted, involved helium $\left({ }^{3} \mathrm{He}\right)$ used in neutron detectors, the demand for which was expected to increase significantly following the events of September 11, 2001. In response, GE worked with several entities to assure future supplies, developed a reclamation system for helium recycling and developed a boron-based system to replace helium-based systems for neutron detection.

3·2. National and regional perspectives. - A national or (multinational) regional perspective is different than a corporate perspective. National and regional perspectives to date have focused on the vulnerabilities of national or regional manufacturing sectors to supply disruptions of important raw materials. Two studies illustrate this perspective.

European Commission [10] evaluates raw materials from the perspective of the European manufacturing sector. It evaluates criticality in two dimensions: a) supply risk based on substitutability, end-of-life recycling, and concentration of production in countries with poor governance; and b) importance of a raw material to European manufacturing, based on the gross value added of a sector. It evaluates fifty-four materials and finds that twenty exceed thresholds for supply risk and importance to qualify as critical.

Daisuke [11] assesses the perspective of the Japanese manufacturing sector using a modified version of the methodology used above for the European Union. The important modifications are incorporating the concentration by country of both reserves and Japanese import partners into the estimate of supply risk. Daisuke evaluates forty-one elements or groups of elements and, significantly, does not use this evaluation to create a list of critical materials; rather he simply displays relative degrees of supply risk and economic importance in a two-dimensional figure.

3.3. A world perspective. - The broadest perspective is that of the world. Graedel et al. [12] present such a perspective, which additionally is noteworthy because of its methodology and timeframe. Of the studies considered here, Graedel et al. [12] is the only one that a) incorporates environmental implications for human health and ecosystems into its methodology and b) explicitly considers the long term, in this case 10-50 years into the future.

3.4. Comparisons. - Tables I, II and III summarize the essential features of the major criticality assessments described above (scope and time frame, indicators of criticality and findings, respectively). They demonstrate the variety and diversity of analyses, suggesting to me, at least, that developing one definitive list of critical raw materials, applicable to all circumstances, is futile. Despite the common focus on criticality, these studies illustrate important differences in the following respects:

- Elements or materials evaluated: Which materials are evaluated necessarily reflects the perspective of the entity undertaking the evaluation.

- Time frame (explicitly forward looking or not): Some studies represent a description of the present and thus are useful for evaluating the near future. Others are 
TABle I. - Assessing criticality: scope and time frame. Sources: GE [8,9], Japan [11], European Union [10], World [12].

\begin{tabular}{|c|c|c|}
\hline & Scope of analysis & Time frame \\
\hline \multicolumn{3}{|l|}{ Corporate } \\
\hline $\begin{array}{l}\text { General Electric } \\
(2011)\end{array}$ & $\begin{array}{l}20 \text { unspecified elements important to } \\
\text { GE products, including } 9 \text { rare earths, } \\
\text { emphasizing minor metals }\end{array}$ & $\begin{array}{l}\text { Unspecified, implicitly a description } \\
\text { of the present and thus relevant for } \\
\text { up to about a decade into the future }\end{array}$ \\
\hline
\end{tabular}

National or

Regional

\begin{tabular}{ll}
\hline $\begin{array}{l}\text { European } \\
\text { Union } \\
(2014)\end{array}$ & $\begin{array}{l}54 \text { non-energy, non-agricultural } \\
\text { materials (rare earths considered in } \\
\text { three groups: light, } \\
\text { heavy \& scandium) }\end{array}$ \\
Japan (2015) & $\begin{array}{l}41 \text { elements or groups of elements } \\
\text { important for Japanese manufacturing } \\
\text { (the element groups are heavy } \\
\text { rare earths, light rare earths and } \\
\text { platinum-group metals) }\end{array}$
\end{tabular}

Unspecified, implicitly a description of the present and thus relevant for up to about a decade into the future

Unspecified, implicitly a description of the present and thus relevant for up to about a decade into the future rare earths, light rare eart
platinum-group metals)

World

Graedel et al. 62 metals and metalloids, (2015) including 15 rare earths

Long term, 10-50 years into the future

explicitly forward looking and evaluate what materials might become "at risk" in the medium or long term.

- Methodology (indicators, quantitative or qualitative assessment): All studies capture to some degree the concepts of supply risk and the impact of a supply disruption should it occur. But the indicators used for supply risk and impact vary considerably from one study to another. Moreover, the degree to which these indicators are based on quantitative data or qualitative judgments also varies from case to case.

- Presentation of findings: Some studies label specific elements or materials as "critical", implying that others are not critical (an "either/or" view of criticality). Other studies, in contrast, embrace criticality as a "more or less" concept and present results that rank elements or materials according to their degree of supply risk and impact of a supply disruption should it occur. 
TABle II. - Assessing criticality: indicators. Sources: GE [8,9], Japan [11], European Union [10], World [12].

\begin{tabular}{lll}
\hline & Indicators of supply risk & Indicators of impact of a supply disruption \\
\hline Corporate & & \\
\hline General Electric & & \\
$(2011)$ & Substitutability & Evaluated as impact on GE, based on: \\
& Demand risks & Impacted GE revenue, \\
& Sourcing \& geopolitical risks & GE purchases as \% of world production, \\
& Historical price volatility & Ability to pass through cost increases to \\
& Co-production risk & customers, Substitutability \\
& Crustal abundance & \\
&
\end{tabular}

National or

Regional

\begin{tabular}{|c|c|c|}
\hline European & Substitutability & Evaluated as economic importance to \\
\hline Union & End-of-life recycling rates & European Union manufacturers, based on: \\
\hline$(2014)$ & $\begin{array}{l}\text { Concentration of primary } \\
\text { production in countries } \\
\text { with poor governance }\end{array}$ & Gross value added of end-use megasectors \\
\hline Japan $(2015)$ & Substitutability & Evaluated as economic importance to \\
\hline & End-of-life recycling rates & Japanese manufacturers, based on: \\
\hline & Concentration of primary & Average import price, Quantity of \\
\hline & $\begin{array}{l}\text { production in countries } \\
\text { with poor governance }\end{array}$ & $\begin{array}{l}\text { domestic demand, Gross value added } \\
\text { by consuming sectors }\end{array}$ \\
\hline & $\begin{array}{l}\text { Country concentration } \\
\text { of reserves }\end{array}$ & \\
\hline & $\begin{array}{l}\text { Concentration of import } \\
\text { partner countries }\end{array}$ & \\
\hline \multicolumn{3}{|l|}{ World } \\
\hline $\begin{array}{l}\text { Graedel et al. } \\
(2015)\end{array}$ & $\begin{array}{l}\text { Depletion time } \\
\text { Co-production ( } \% \text { mined } \\
\text { as a by-product) }\end{array}$ & $\begin{array}{l}\text { Evaluated as vulnerability to a supply } \\
\text { restriction, based on: Economic importance, } \\
\text { Substitutability }\end{array}$ \\
\hline
\end{tabular}

- Specific findings: Not surprisingly given the differences noted above, each study comes to somewhat different specific findings. Nevertheless, a number of elements, or types of elements, appear as critical across the range of studies reviewed here: rare earth elements, and those produced largely as by-products of other, major materials (for example, cobalt, gallium, germanium, hafnium, indium, rhenium, and tellurium). 
TABle III. - Assessing Criticality: findings. Sources: GE [8,9], Japan [11], European Union [10], World [12].

\begin{tabular}{lll}
\hline & Reporting of findings & Specific findings \\
\hline Corporate & & \\
\hline General Electric (2011) & $\begin{array}{l}\text { No explicit "critical" list. } \\
\text { Results displayed on } \\
\text { a 2-dimensional figure. }\end{array}$ & $\begin{array}{l}\text { Specific elements not identified, al- } \\
\text { though } 8 \text { of the } 9 \text { rare earths appear } \\
\text { among the relatively more critical } \\
\text { elements }\end{array}$
\end{tabular}

National or

Regional

European Union (2014) 20 materials identified as "critical" based on thresholds for supply risk and economic importance. Results also displayed on a 2dimensional figure.

Critical: antimony, beryllium, borates, chromium, cobalt, coking coal, fluorspar, gallium, germanium, indium, magnesite, magnesium, natural graphite, niobium, platinum group metals, phosphate rock, heavy rare earths, light rare earths, silicon metal, tungsten

Japan (2015) No explicit "critical" list. Results displayed on a 2dimensional figure.
Among the relatively more critical: antimony, germanium, graphite, niobium, magnesium, platinum group metals, silicon, tungsten, heavy rare earths, light rare earths

World

Graedel et al. (2015)

No explicit "critical" list. Results displayed in a 3-dimensional criticality space. Cluster analysis used to identify groups with similar degrees of criticality.

\begin{abstract}
Specific results difficult to summarize. From the abstract: "The metals of most concern tend to be those available largely or entirely as byproducts, used in small quantities for highly specialized applications and possessing no effective substitutes."
\end{abstract}

\section{4. - Technological perspectives and clean energy}

Narrowing our focus, a technological perspective on criticality concentrates on the vulnerability of a particular technology to supply disruptions for important raw materials. For emerging technologies, it is the development and deployment of the technology that 
TABle IV. - Potentially Critical Materials for Selected Clean-Energy Technologies. Sources: [1320] and author's experience.

\begin{tabular}{ll}
\hline Technology & Potentially critical materials \\
\hline Batteries & \\
Lead acid & Lead \\
Nickel metal hydride & Lanthanum, nickel \\
Lithium ion & Cobalt, graphite, lithium \\
Emerging & Magnesium, vanadium \\
Solar power & \\
Silicon based & Nickel, silver, tin \\
Copper-indium-gallium selenide & Gallium, indium, selenium \\
Cadmium telluride & Tellurium \\
Magnets (for high efficiency motors) & Cobalt, nickel \\
Alnico & Cobalt, samarium \\
Samarium-cobalt & Dysprosium, neodymium, praseodymium, terbium \\
Neodymium-iron-boron & \\
Lighting & Cerium, europium, lanthanum, manganese, \\
Fluorescent & terbium, yttrium \\
Light-emitting diodes (LEDs) & Cerium, europium, gallium, germanium, indium, \\
lanthanum, nickel, silver, terbium, tin, yttrium \\
Fuel cells
\end{tabular}

is at risk. For selected energy technologies, table IV summarizes potentially critical elements, many of which are the same as those identified by the broader criticality studies described above.

Two organizations have devoted considerable attention to identifying and prioritizing critical elements for clean-energy technologies, the U.S. Department of Energy and the European Commission's Joint Research Centre. Table V summarizes these studies.

4 1. U.S. Department of Energy. - Studies by the U.S. Department of Energy (DOE) in 2010 and 2011 use an extended version of the NRC framework to identify critical elements for selected materials in electric vehicles, fluorescent lighting, photovoltaic 


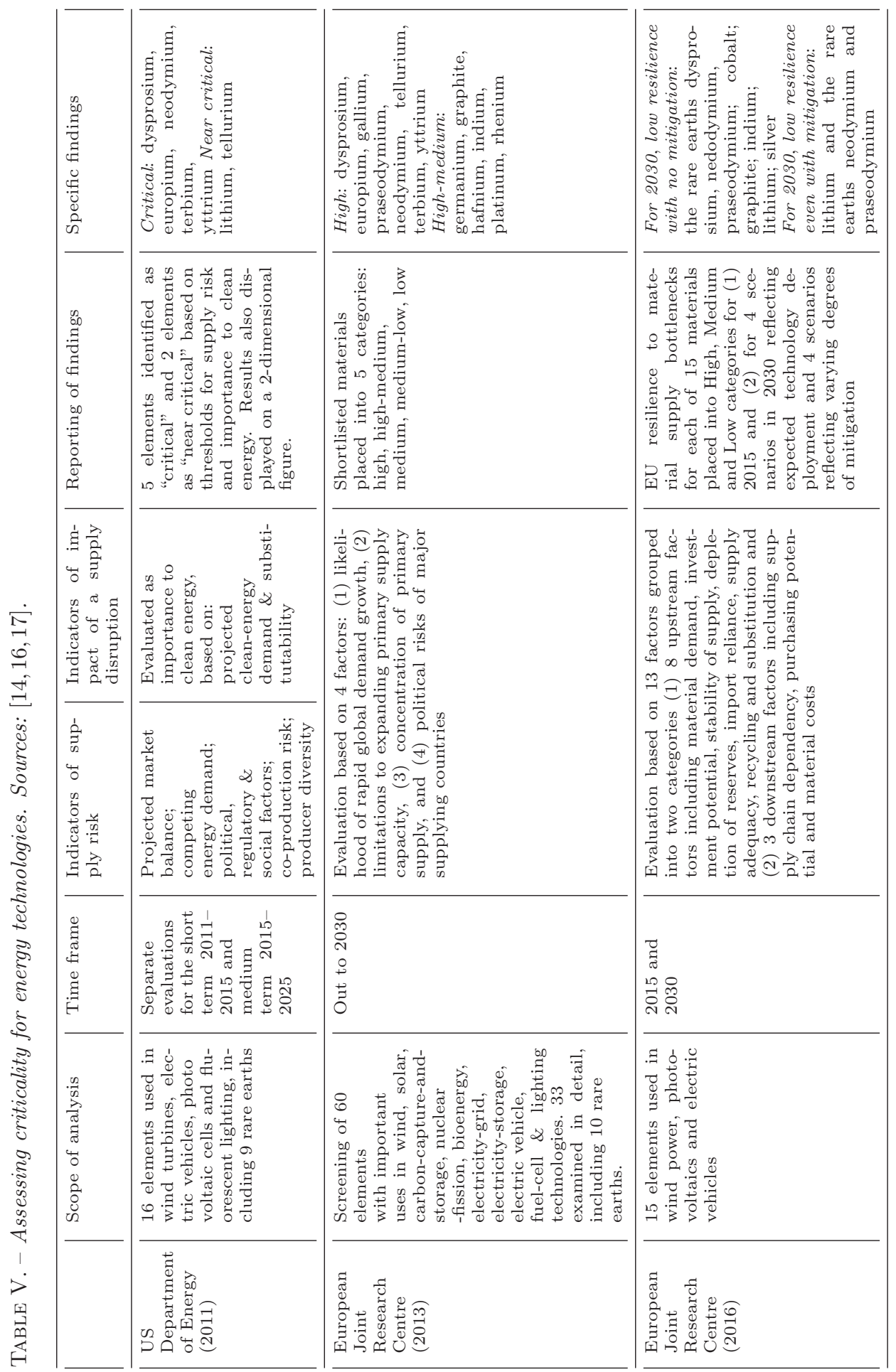


power systems, and wind turbines $[13,14]$. These studies evaluate supply risk on the basis of forward-looking calculations of the balance between production and demand for an element; competing technology demand; political, social and regulatory factors; co-production; and producer diversity (or lack thereof). These studies evaluate the second dimension of criticality, importance to clean energy, on the basis of likely growth in clean energy demand for an element, and ease or difficulty of substituting away from an element should a supply disruption occur. DOE evaluates sixteen elements and, in the 2011 study finds the rare earths dysprosium, europium, neodymium, terbium, and yttrium to be critical, with lithium and tellurium as near critical, looking forward five to fifteen years. In addition, these studies articulate a strategy for reducing supply-chain risks though innovation in three areas: process engineering to facilitate more efficient primary production, process engineering to increase manufacturing efficiency and recycling, and materials science and engineering to develop substitute materials.

4.2. European Joint Research Centre. - Studies published in 2011, 2013 and 2016 by the European Commission's Joint Research Centre (JRC) evaluate critical metals in the energy sector [15-17]. The 2011 and 2013 studies evaluate a broader set of technologies and materials than the U.S. DOE studies described in the previous section. The 2011 study encompasses the nuclear-fission, solar, wind, bioenergy, carbon-capture-andstorage, and electricity-grid sectors. The 2013 study includes the same six sectors and adds eleven technology sectors including fuel cells, electric vehicles, electricity storage and lighting. In the 2013 study, JRC evaluates sixty elements for possible detailed study and then studies thirty-two elements in some depth —using a methodology that considers likelihood of rapid demand growth, limitations on the ability to expand production capacity for an element experiencing demand growth, geographic concentration of production, and political risk. It identifies eight elements as critical: the rare-earth elements dysprosium, europium, neodymium, praseodymium, terbium, and yttrium, as well as gallium and tellurium. It identifies four materials as near critical: graphite, indium, platinum, and rhenium.

The 2016 JRC study is narrower in scope than the 2011 and 2013 studies, evaluating potential supply-chain bottlenecks for fifteen materials providing important functionality to systems in wind power, photovoltaics and electric vehicles. It assesses the situation in 2015 and then identifies potential bottlenecks in 2030 under forecasted deployment of these technologies under four scenarios that differ in the degree to which they incorporate measures to mitigate supply-chain risks - recycling, European Union (EU) production and substitution. With no mitigation, materials for which supply-chain resilience in the EU would be low in 2030 are: dysprosium, neodymium, praseodymium (wind power and electric vehicles), indium and silver (photovoltaics) and cobalt, graphite and lithium (electric vehicles only). With effective mitigation, supply-chain resilience in 2030 would be low only for neodymium, praseodymium and lithium. The JRC methodology in the 2016 study is noteworthy because it explicitly considers (separately) the upstream and downstream portions of the supply chains. 
4.3. Other energy studies. - Several studies are narrower in scope or less detailed in their analysis of energy technologies and criticality.

A 2011 monograph by Achzet et al. [18], describes supply chains for nineteen elements or families of elements that provide important functionality in the oil, biomass, natural gas, coal, nuclear, geothermal, wind, hydro, and solar sectors. It subjectively assigns supply risk scores of high, medium, or low. The elements or families of elements receiving high-risk scores are: cadmium, chromium, cobalt, gallium, germanium, platinum, rare earths, rhodium, tellurium, and uranium.

A 2014 paper by Goe and Gaustad [19] evaluates critical materials for photovoltaics in the United States. It evaluates seventeen elements and, of these, finds six to be most critical: arsenic, germanium, indium, platinum, silver, and tin. The paper evaluates three types of risk: a) supply risk, based on net import reliance, concentration of production, recycling rates, and ratio of production to reserves; b) environmental risk, based on human toxicity, primary embodied energy, and energy savings; and c) economic risk, based on material price, domestic consumption, and economic value of the sector.

Another 2014 paper, this one by Roelich et al. [20] develops a methodology for evaluating supply risks dynamically - focusing on changes in criticality during the transition to electricity generation that produces lower carbon emissions than at present. The authors demonstrate their methodology by applying it to neodymium and the power sector of the United Kingdom.

\section{5. - What to do?}

As noted earlier, there are three obvious responses that have the potential to mitigate criticality: 1) increase and diversify primary production, 2) enhance the efficiency with which we use materials (increased manufacturing efficiency, material re-use and recycling) and 3) develop substitute materials. From the perspectives of governments and public policy, however, the central issue is determining who should be responsible for undertaking these responses.

Natural market forces provide powerful incentives for material users and producers, most of whom are not governments, to respond to criticality. Thus my personal view is that the primary responsibility rests with material users and producers, including potential producers. Users, typically manufacturers of components and assemblies destined for final products, should act in their own self interests to evaluate and secure their supply chains - in effect, buying insurance against supply-chain disruptions through one or a combination of activities such as entering strategic alliances with material suppliers, diversifying sources of supply, and over the longer term perhaps developing substitute materials. Similarly, as long as markets properly signal supply-chain risks, then material producers (actual and potential) will act to develop new and more diversified sources of supply by investing in mineral exploration, mine development, and technological research that improve material supplies.

Public policy, in turn, should focus on activities that enhance the functioning of markets, especially when markets do not work well on their own. Specifically, as noted 
in Eggert [21,22]:

- Facilitating international trade when trade restrictions are a significant source of supply-chain risk.

- Facilitating development of new mines and processing facilities when undeveloped resources are known to (or may conceivably) exist.

- Investing in the provision of basic market information and strategic analysis, on which actual material users and producers can make informed decisions about critical materials (a key difficulty that market participants face in making informed decisions about many critical materials is, arguably, that many of critical-material markets are small and opaque - that is, difficult to evaluate on the basis of public information); and

- Investing in research and education over the entire material life cycle.

Information, research, and education are, at least in part, what economists call public goods, in that the private sector alone is likely to underinvest in these activities from society's perspective because the benefits of these investments are risky, far in the future for the most part, and difficult for private investors to fully appropriate.

\section{6. - Conclusions}

Criticality is in the eye of the beholder and has many faces. The perspective of a corporation necessarily differs from that of a nation or region's manufacturing sector, which, in turn, differs from those of an emerging technology or the world as whole. Moreover, criticality is dynamic; what is critical today likely will not be critical in the future because of actions taken today to thwart vulnerability to supply restrictions for important raw materials. Criticality assessment is an important tool for identifying potential problems before they occur.

This paper draws significantly on two earlier papers published in conference proceedings $[23,24]$. This work overall is supported in part by the Critical Materials Institute, an Energy Innovation Hub funded by the U.S. Department of Energy, Office of Energy Efficiency and Renewable Energy, Advanced Manufacturing Office, and the Viola Vestal Coulter Foundation.

\section{REFERENCES}

[1] Jevons W. S., The Coal Question: An Inquiry Concerning the Progress of the Nation, and the Probable Exhaustion of Our Coal Mines (Macmillan \& Co, London and Cambridge) 1865.

[2] Hager T., The Alchemy of Air: A Jewish Genius, A Doomed Tycoon, and the Scientific Discovery That Fed the World But Fueled the Rise of Hitler (Random House, New York) 2008. 
[3] Smil V., Enriching the Earth: Fritz Haber, Carl Bosch, and the Transformation of World Food Production (MIT Press, Cambridge, Massachusetts) 2004.

[4] President's Materials Policy Commission, Resources for Freedom, Vol. 1: Foundations for Growth and Scarcity (U.S. Government Printing Office, Washington, DC) 1952.

[5] Sмiтh V. K. (Editor), Scarcity and Growth Reconsidered (Johns Hopkins University Press for Resources for the Future, Baltimore, Maryland) 1979.

[6] National Research Council, Minerals, Critical Minerals, and the U.S. Economy (National Academies Press, Washington, DC) 2008.

[7] Graedel T. E., Barr R., Chandler C., Chase T., Choi J., Christoffersen L., Friedlander E., Henly C., Jun C., Nassar N. T., Schechner D., Warren S., YANG M. and Zhu C., Environ. Sci. Technol., 46 (2012) 1063, doi:10.1021/es20354z.

[8] Duclos S., Sustainable materials for manufacturing: GE risks and opportunities, paper presented at the GE Whitney Symposium, Niskayuna, New York, October 2011.

[9] Ku A. and Hung S., CEP Magazine, September 2014, pp. 28-35.

[10] European Commission, Report on critical raw materials for the EU, retrieved from http://ec.europa.eu/growth/sectors/raw-materials/specific-interest/critical/ index_en.htm, 2014.

[11] Daisuke A., A study of a stable supply of mineral resources, unpublished study of the Japan Oil, Gas and Metals National Corporation, Tokyo, 2015.

[12] Graedel T. E., Harper E. M., Nassar N. T., Nuss P. and Reck B. K., Proc. Natl. Acad. Sci. U.S.A., 112 (2015) 4257, doi: 10.1073/pnas.1500415112.

[13] Department of Energy, Critical Materials Strategy (U.S. Department of Energy, Washington, DC) December 2010.

[14] Department of Energy, Critical Materials Strategy (U.S. Department of Energy, Washington, DC) December 2011.

[15] Moss R. L., Tzimas E., Kara H., Willis P. and Kooroshy J., Critical Metals in Strategic Energy Technologies (European Union, Luxembourg) 2011.

[16] Moss R., Tzimas E., Willis P., Arendorf J., Tercero Espinoza L. et al., Critical Metals in the Path towards Decarbonisation of the EU Energy Sector: Assessing Rare Metals as Supply-Chain Bottlenecks in Low-Carbon Energy Technologies, JRC Scientific and Policy Report (European Union, Luxembourg) 2013.

[17] Blagoeva D. T., Aves Dias P., Marmier A. and Pavel C. C., Assessment of potential bottlenecks along the materials supply chain for the future deployment of low-carbon energy and transport technologies in the EU, JRC Science for Policy Report (European Union, Luxembourg) 2016.

[18] Achzet B., Reller A. and Zepf V., Materials Critical to the Energy Industry: An Introduction (University of Augsburg, Augsburg) 2011.

[19] Goe M. and Gaustad G., Appl. Energy, 123 (2014) 387.

[20] Roelich K., Dawson D. A., Purnell P., Knoeri C., Revell R., Busch J. and Steinberger J. K., Appl. Energy, 123 (2014) 378.

[21] Eggert R. G., Issues Sci. Technol., XXVI (2010) 49.

[22] EgGert R. G., Nat. Chem., 3 (2011) 688.

[23] Eggert R. G., Proceedings of the World Engineering Conference and Convention, Kyoto, Japan, 2015, paper 20533, oral session 3-2-1.

[24] Eggert R. G., XXVIII International Mineral Processing Congress Proceedings, Quebec City, Canada, 2016 (The Canadian Institute of Mining, Metallurgy and Petroleum) 2016, paper 739 . 